\title{
Mass Rearing of Haplaxius crudus (Hemiptera: Cixiidae), an Important Insect Pest in the Palm Oil Industry of Colombia
}

\author{
Ivette Johana Beltran-Aldana $^{1,}$, , Alex Enrique Bustillo-Pardey ${ }^{2}$, Anuar Morales-Rodriguez $^{2}$ \\ ${ }^{1}$ Entomology Department, Colombian Oil Palm Research Centre, Paratebueno, Colombia \\ ${ }^{2}$ Entomology Department, Colombian Oil Palm Research Centre, Bogotá, Colombia
}

\section{Email address:}

ivbeltran@cenipalma.org (I. J. Beltran-Aldana), abustillo@cenipalma.org (A. E. Bustillo-Pardey), amorales@cenipalma.org (A. Morales-Rodriguez)

${ }^{*}$ Corresponding author

\section{To cite this article:}

Ivette Johana Beltran-Aldana, Alex Enrique Bustillo-Pardey, Anuar Morales-Rodriguez. Mass Rearing of Haplaxius crudus (Hemiptera: Cixiidae), an Important Insect Pest in the Palm Oil Industry of Colombia. American Journal of Entomology. Vol. 4, No. 2, 2020 , pp. $39-44$. doi: $10.11648 /$ j.aje.20200402.13

Received: August 13, 2020; Accepted: August 31, 2020; Published: September 25, 2020

\begin{abstract}
The palm leafhopper, Haplaxius crudus (Van Duzee) (Hemiptera: Cixiidae), is a vector of the pathogen that causes the lethal wilt disease in oil palm in Colombia. The development of a methodology for mass rearing of this insect is required to study its biology, behavior, population control, and to determine the causal agent of the lethal wilt disease. The experiment was carried out in Colombia, at the Research Experimental Center "Palmar de las Corocoras" of Cenipalma. The environmental conditions of the rearing unit during the study were $25.7 \pm 3.4^{\circ} \mathrm{C}$, and $85 \pm 13 \% \mathrm{R}$. H. The mass production of $H$. crudus required the performance of five processes: 1) Planting and maintenance of Panicum maximum Jacq. cv. Mombasa grass, which hosts $H$. crudus nymphs, and of coconut palms (Cocos nucifera L.) var. dwarf yellow, to hold the adult insects; 2) Collecting nymphs in fields to create a breeding stock; 3) Infesting clumps of $P$. maximum grass with $H$. crudus eggs; 4) Maintaining the infested clumps, and 5) Trapping of emerging adults in cages. The time from the infestation of the clumps of grass, to the emergence of adults took $56.2 \pm 4.1$ days. The rearing unit reached an average production of 3,145 adults per week $(52.8 \%$ female and $47.2 \%$ male). The development of this rearing enables the production of enough $H$. crudus individuals to research lethal wilt, to mitigate the impact of this disease on the Colombian oil palm growing industry.
\end{abstract}

Keywords: Mass Production of Insects, Lethal Wilt, Palm Leafhopper

\section{Introduction}

The palm leafhopper, Haplaxius crudus (Van Duzee) (Hemiptera: Cixiidae), was first described in 1907 in Jamaica. It is present in southern Florida and has been reported in Cuba, Cayman Islands, Trinidad, and in the meridional area of tropical America, from Mexico to northern South America [1], including Brazil [2]. The adult of $H$. crudus is the only insect considered to be a vector for the lethal yellowing of coconut palms (Candidatus Phytoplasma palmae), a highly destructive disease for coconut and ornamental palms in Florida and several countries in the Caribbean Basin [1].

In Colombia, H. crudus is responsible for the dissemination of the pathogen that causes the lethal wilt (L. W.) disease in oil palm [3]. This disease has spread to plantations of the departments of Meta and Casanare and is the main plant health issue for oil palm in the Eastern Palm Growing Region of Colombia. The first cases of L. W. were reported in Bajo Upía (Casanare) in 1994 [4]. Between 1997 and 2018, a total of 911,738 palms infested with lethal wilt were eradicated $[5,6]$.

The life cycle of $H$. crudus includes the egg, nymph, and adult stages. Haplaxius crudus females lay eggs in the soil, close to the base of stalks of grasses and under drying leaf sheaths [7]. When the nymphs emerge, they move towards the roots of grasses to feed and remain in nests built with secreted silk from abdominal glands $[7,8]$. When $H$. crudus reach the adult stage, they fly towards palm leaves and stay on the underside of the leaves to mate and feed by sucking the palm's sap. Females later return to grassy areas to lay their eggs and continue their reproductive cycle $[2,9]$. The total life cycle of H. crudus under shaded roof conditions $\left(26.5 \pm 4.1^{\circ} \mathrm{C}\right.$; R. H.: 
$58.1 \pm 14.6 \%$ ) takes $63.7 \pm 3.6$ days [10], with the egg stage lasting $15.4 \pm 0.9$ days, the nymph stage (including five instars) lasting $48.3 \pm 2.7$ days, and total life span of adults lasting $19.7 \pm 10.9$ days.

Research previously conducted at Cenipalma reported a higher proportion of males than females $(7: 1)$ in the palm's leaves. The lower abundance of females on palm's leaves is explained because they remain part of the day in clumps of grass to lay their eggs near the base of the grass stalks [9]. In these investigations, they also mentioned that it is possible to find more adults between 07:00 - 9:00 and 16:00 - 18:00, sampling with an entomological net.

Haplaxius crudus is an important insect pest for Colombian oil palm cultivars because it is a vector of the pathogen that produces the lethal wilt disease [3]. For the Colombian palm oil industry, extensive research is required to understand the etiology of lethal wilt and the role of H. crudus in the infection and dispersal process and to develop an early detection method to minimize oil palm losses in the plantation. These studies also include biology, phenology, and population dynamics of $H$. crudus to develop an integrated pest management program. However, previous attempts to mass-produce these insects have not been successful due to the lack of adequate facilities, efficient and standardize control processes, and operators trained in the daily activities involved in managing rearing insects of this nature $[11,12]$. Therefore, efforts are needed to develop an effective and continuous process for mass rearing $H$. crudus to reach an adequate scale of the population to perform the research aimed at reducing the impact of lethal wilt on Colombian oil palm plantations.

\section{Materials and Methods}

\subsection{Location}

The H. crudus rearing unit is located at Cenipalma's Experimental Field "Palmar de Las Corocoras" (CEPC, for the name Spanish) in Paratebueno, Cundinamarca, at an altitude of 227 masl, the latitude of $4^{\circ} 22^{\prime} 04^{\prime \prime} \mathrm{N}$ and longitude of $73^{\circ} 10^{\prime} 16^{\prime \prime} \mathrm{W}$. The average temperature at the unit is $25.7 \pm 3.4^{\circ} \mathrm{C}$, the relative humidity of $85 \pm 13 \%$ and an average annual rainfall of $2,454 \mathrm{~mm}$.

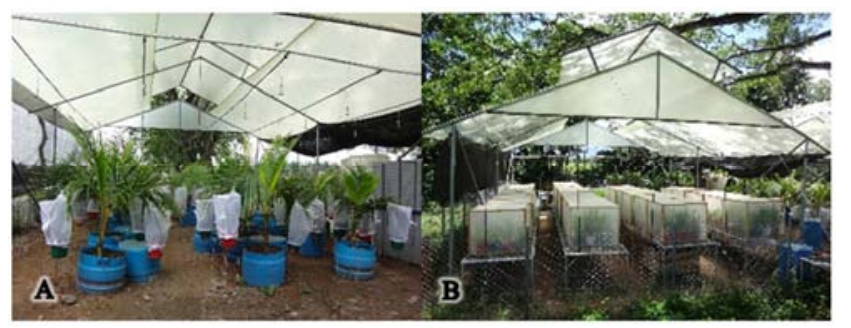

Figure 1. Rearing unit de Haplaxius crudus. A. The module of infestation with coconut palms in drums and egg-laying cages in the foliage. $B$. The module of maturation and emergence with cube-shaped cages covered with anti-aphid mesh to handle the infested clumps of grass and the emergence of H. crudus adults.
The rearing unit consisted of two modules of shading roofs, each equipped with an automated mist system for temperature and humidity control. The first module used for infestation contained coconut palms (Cocos nucifera L.) and egg-laying cages. (Figure 1A). The second module used for maturation and emergence included cages to manage the grass clumps for early development and adult stage of $H$. crudus (Figure 1B).

\subsection{Host Plants}

Based on early evidence for host preference, the plant material to host the nymphs of $H$. crudus was obtained from commercial seeds of Panicum maximum Jacq. cv. Mombasa (Pastos y Leguminosas S. A, Villavicencio, Colombia [2, 8, 13]. The protocol from Moya and Bustillo 2015 was used for this study [11]. In brief, the seeds were planted in plastic pots of 0.751 (HDienes S. A. S, Bogotá, Colombia, plastic plant pots \# 12), by uniformly distributing $0.15 \mathrm{~g}$ of seeds over a substrate consisting of two parts of previously solarized soil, one part of peat, and one part of coconut fiber. Five weeks after planting the grass, this was transplanted by removing the clump of grass from the germination pots (Figure 2A) and placing it in a larger plant pot of 51 (HDienes, Bogotá, Colombia, plastic plant pots \# 23). The pots were filled with soil to $2 / 3$ of its capacity (Figure $2 \mathrm{~B}$ ). The clump of grass was fertilized with $2 \mathrm{~g}$ of NPK plus Phytohormones (Rebrote ${ }^{\circledR}$, Kibutzim Ltda, Bogotá, Colombia) and $2 \mathrm{~g}$ of urea (Yara Colombia S. A, Bogotá, Colombia). The plant pot was covered with an aluminized thermal insulator, with a thickness of $5 \mathrm{~mm}$ (Thermolon, PlastiTek S. A. S, Bogotá, Colombia); in the center of the cover, a hole was made through which the leaves of the grass came out (Figure 2C). In this way, a dark and wet chamber was created to favor the development of rootlets, which are essential factors for the survivorship of the nymphs [14]. After four weeks of growth, the plant material was ready to begin infestation with $H$. crudus adults (Figure 2D).
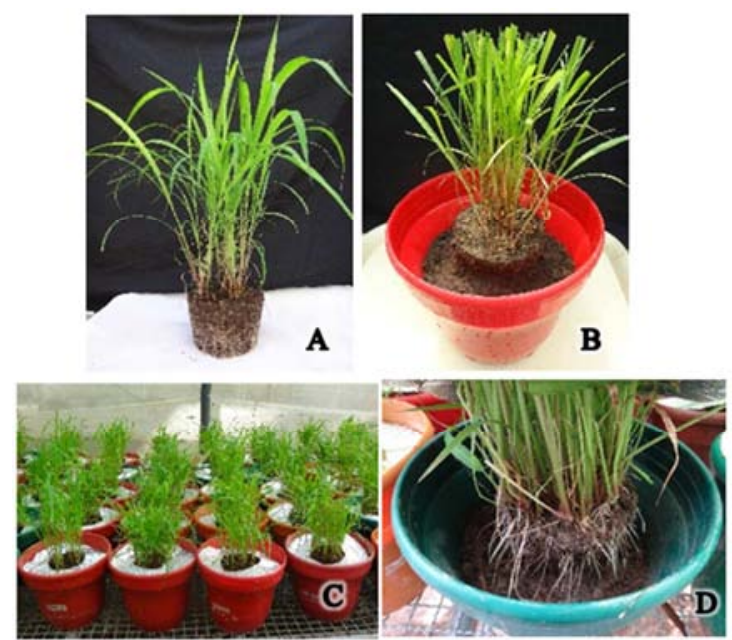

Figure 2. Transplantation of Panicum maximum. A. Picture of a clump of grass five weeks after planting. B. Clump took from a \# 12 plant pot placed in a \# 23 plant pot. C. Clumps in \# 23 plant pots covered with Thermolon. C. Picture of a clump four weeks after transplanting, observe the side rootlets. 
Coconut palm, dwarf yellow variety, between 12-18 months old, were used as a food resource for H. crudus adults [11]. Palm trees were acquired from a commercial nursery (Don Juan Vivero, Meta, Colombia) and were transplanted in plastic drums with a diameter of $60 \mathrm{~cm}$ and a depth of $50 \mathrm{~cm}$, to facilitate handling [11]. Palms were watered once a week, and fertilization was conducted every three months with $40 \mathrm{~g}$ of an edaphic fertilizer grade 19-4-19-3 (YaraMila Hydran, Yara Colombia, Bogotá, Colombia). In addition, frequent scouting was conducted to evaluate the presence of spiders and ants, considered predators of $H$. crudus.

\subsection{Initial Population}

The population of $H$. crudus to start the mass rearing was collected from oil palm plantations. Clumps of $P$. maximum and Paspalum virgatum L. infested with immature insects were collected [3, 11] (Figure 3).

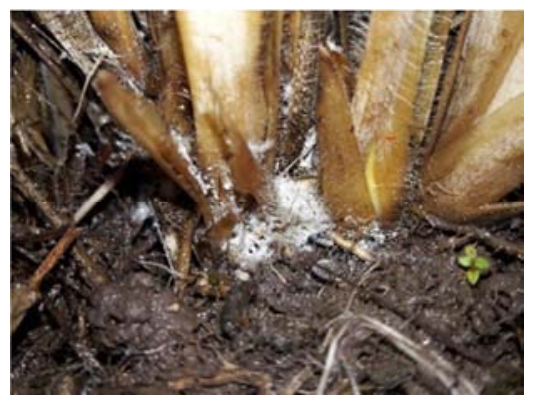

Figure 3. A clump of Panicum maximum grass with Haplaxius crudus nymphs.

The clumps were extracted from the soil, and the roots were placed in black plastic sheets to facilitate the collection of the nymphs [13]. The nymphs were carefully collected using soft tweezers and small plastic spoons. Groups of approximately 100-150 nymphs were placed in containers with roots of the host grass [12]. Later, these containers were placed inside a polystyrene cooler, with a cooling gel pad to maintain the viability of the nymphs during their transfer to the rearing unit.

\subsection{The Infestation of Clumps of Grass}

The oviposition cages were formed using the clumps of $P$. maximum grass grown at the rearing unit, and the coconut palms planted in drums. These conditions simulate the process that takes place in the field: the adults fly to the palms, feed on them, copulate, and then the females fly down to lay the eggs on the neck of the root of the grass stalks, to enable the emerging nymphs to feed off the grass rootlets.

The oviposition cage consisted of a frame of rectangular-shaped iron rods $(20 \mathrm{~cm}$ wide x $28 \mathrm{~cm}$ long $\times 60$ $\mathrm{cm}$ tall), placed above the clump of $P$. maximum grass (Figure 4A), and covered with a nylon cloth liner (Figure 4B). This cloth was attached to the plant pot and the tip of the coconut palm leaf with an elastic band (Figure 4C). The purpose of this was to arrange in the nylon liner (Figure 4D) to enable the introduction of between 10 and 20 pairs of $H$. crudus adults from the rearing unit. The $H$. crudus adults were held for eight days to ensure that they coupled and laid eggs.

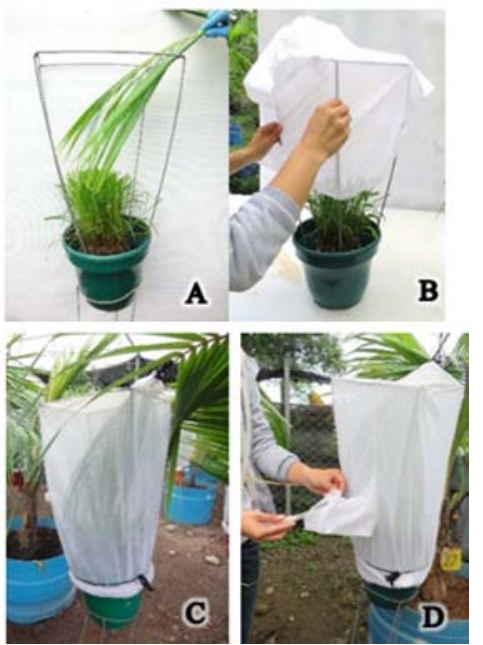

Figure 4. Setting up the Haplaxius crudus egg-laying cage. A. The metal frame over the plant pot with a clump of Panicum maximum and location of the coconut palm leaf. B. Placing the nylon cloth liner over the metal frame. $C$. Nylon cloth liner is attached to the plant pot and the coconut palm leaf using elastic textile. D. Introduction of Haplaxius crudus adults in the egg-laying cage.

\subsection{Maintenance of the Infested Clumps of Grass}

The infested clumps in the initial egg-laying cages were transferred to cube-shaped baskets made from aluminum angle bars ( $1.0 \mathrm{~m}$ wide x $1.0 \mathrm{~m}$ long x $0.8 \mathrm{~m}$ tall), which were covered with an anti-aphid mesh, and closed with Velcro strips placed on the opposite sides. Each can host 16 plant pots with clumps of grass [11] (Figure 5A). These clumps remained in the baskets until the emergence of the $H$. crudus adults was completed.

The plant pots with the clumps were moistened using a manual sprayer, aiming the water at the base of the clump. Manual pest control was performed, and they were trimmed once a week. Fertilizer was applied monthly using the Tottal ${ }^{\circledR}$ (Colinagro S. A, Bogotá, Colombia) leaf fertilizer, with a dilution of $15 \mathrm{cc} /$ liter of water. Whenever low growth of roots in clumps was observed, the Hormonagro $1{ }^{\circledR}$ (Colinagro S. A, Bogotá, Colombia) physiological regulator fertilizer was added in a dosage of $1 \mathrm{mg} / 1$.
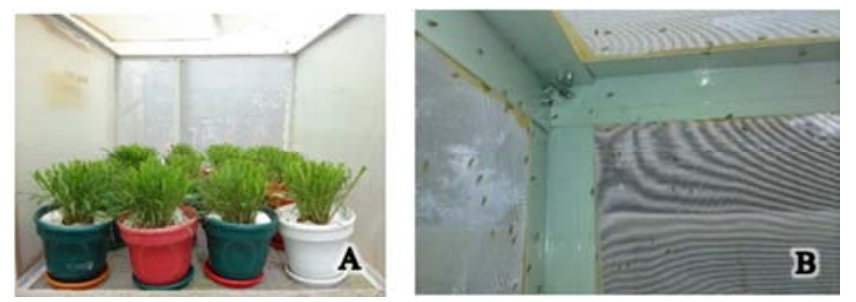

Figure 5. Development and recovery of Haplaxius crudus adults in the breeding unit. A. Clumps of Panicum maximum grass infested with eggs to obtain adults. B. Emerging Haplaxius crudus adults in the cage.

\subsection{The Emergence of H. crudus Adults}

Newly emerged adults were collected daily. The clumps were spraying with water to facilitate the collection; this made 
them fly towards the cage walls (Figure 5B), where they are collected with a mouth aspirator. All the trapped H. crudus adults were counted, sexed (Figure 6), and used for research purposes while maintaining $50 \%$ of the population to develop the mass rearing.

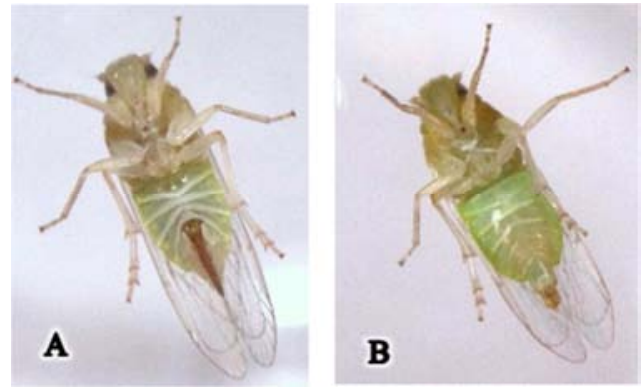

Figure 6. Details of the sexual dimorphism of Haplaxius crudus adults. A. Female. B. Male.

\section{Results and Discussion}

\subsection{Host Plants}

Every week, an average of 100 clumps of $P$. maximum were planted to maintain enough amounts for infestation with $H$. crudus. The coconut palms were replaced every six months, once they had surpassed the required age and height for the mass rearing, or whenever they displayed severe attacks from the red mite, Raoiella indica Hirst. (Acari: Tenuipalpidae) [15]. Tsai et al. [16] and Eden-Green [17] in Florida, made colonies de $H$. crudus on a small scale, under laboratory conditions using a different grass variety, Stenotaphrum secundatum Walt., to studies the transmission by H. crudus of the agent that causes lethal yellowing of coconut palm. This type of grass was not used in this study because it was not present in the oil palm ecosystems of the eastern Colombian region [13]. P. maximum was used to obtain $H$. crudus eggs because it is common in Colombian oil palm regions, and this insect prefers laying eggs in this grass variety.

\subsection{Initial Population}

A total of 21,335 H. crudus nymphs were collected between instar III and V to establish and maintain the breeding stock during the two-years cycle of this study. A total of 10,390 adults emerged $(48.7 \%)$, and $56 \%$ of the adults were females. $71 \%$ of nymphs of instar $\mathrm{V}$ reached the adult stage, which makes this instar the most appropriate for build the mass rearing. Instead, a lower proportion of nymphs in instar III and IV reached the adult stage: $34.3 \%$ and $45.2 \%$, respectively.

Even though the percentage of $H$. crudus nymphs that reached the adult stage was low, and in other studies they used adults collected in the field to start up the mass rearing $[11,17]$, here we found that nymphs collected in the field are the safest way to obtain the initial population of $H$. crudus, and not having the risk of introducing adults to the rearing unit that have possibly acquired the L. W. pathogen in the field.

\subsection{The Infestation of Clumps of P. maximum}

The $H$. crudus adults from the initial breeding stock and their offspring were used for reproduction. A total of 115,232 females and 105,248 males of $H$. crudus, were used to infest 6,490 clumps of $P$. maximum. $57 \%$ of the adults used for infestation have newly emerged youths, and the remaining $43 \%$ were older adults that were removed from the egg-laying cages after the infestation period (30\% 8-day-old adults, $11 \%$ 16-day-old adults, and 2\% 21-day-old adults since emergence).

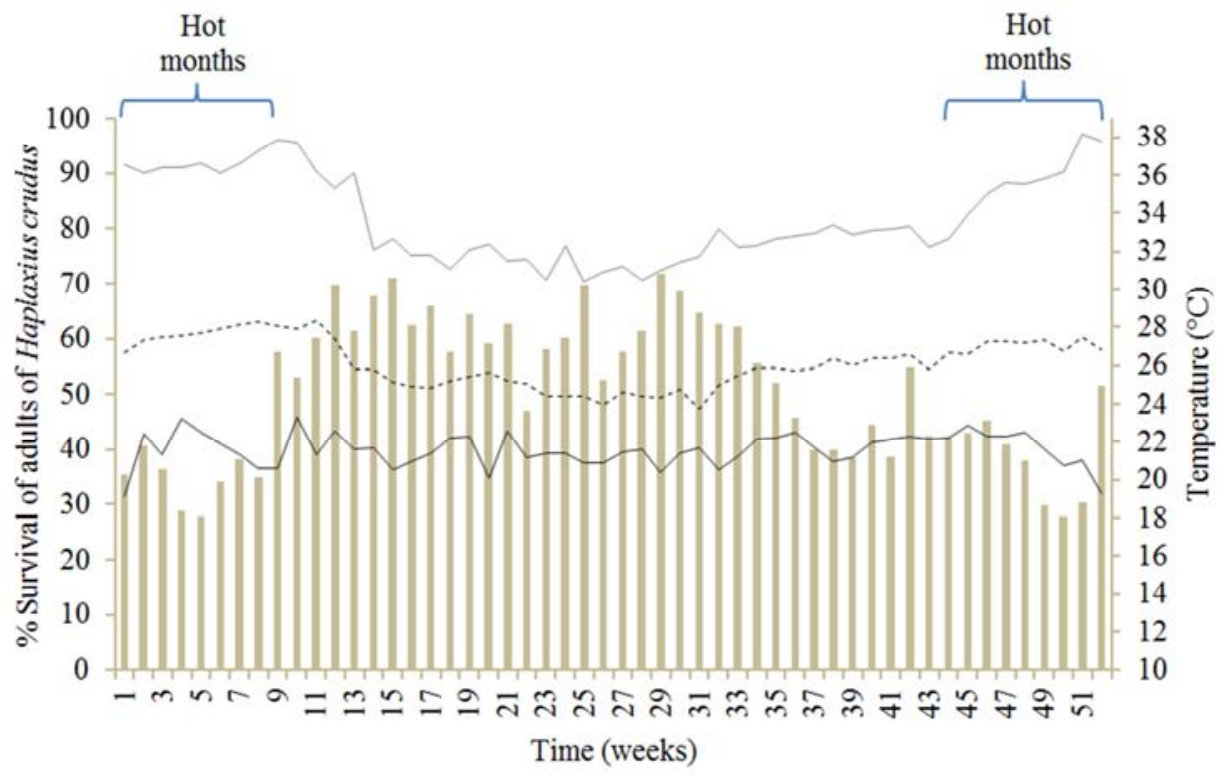

Adult survival (\%)

Average temperature $\left({ }^{\circ} \mathrm{C}\right)$

Maximum temperature $\left({ }^{\circ} \mathrm{C}\right)$ Minimum temperature $\left({ }^{\circ} \mathrm{C}\right)$

Figure 7. Percentage of survival of Haplaxius crudus adults inside the egg-laying cages. Observe the reduction in the warmer months of the year in the area where the breeding unit is located. 
This activity must be carried out by trained personnel, because trapping the $H$. crudus adults abruptly using the mouth aspirator can cause the premature death of the adults, then causes a reduction in the number of laid eggs, leading therefore to lower production of $H$. crudus adults. Also, the infestation of the clumps seems to be affected by high temperatures, reducing adult survival rates in the egg-laying cages at the rearing unit located at Palmar de las Corocoras. High temperatures happen mainly in the periods of January-February and November-December (Figure 7). This limiting factor was mitigated at the rearing unit by installing a mist system, with temperature and humidity control, to maintain the most suitable temperature for insect development.

\subsection{Maintenance of the Infested Clumps of Grass}

Haplaxius crudus colony was maintained free of predator arthropods and grass pests. The most frequent predators at the $H$. crudus breeder were spiders, mainly of the genus Theridion Walckenaer (Araneae: Theridiidae), which were found inside the cages from which the $H$. crudus adults emerged. This spider genus has been found in Florida (USA) as a predator of
H. crudus adults present in coconut palms [18]. In the host grasses, the most common pests were nymphs of grass spittlebugs, Aeneolamia varia Fabricius (Hemiptera: Cercopidae), and defoliating larvae of different types of Lepidoptera.

\subsection{The Emergence of $\mathrm{H}$. crudus Adults}

The emergence of adults displayed a variable pattern (Figure 8). We suggest maybe one of the causes was an uneven infestation of $P$. maximum clumps each week. The availability of adults for infestation depended on the number of insects required for the research studies. The time elapsed, from the infestation of the clump with $H$. crudus eggs to the emergence of the adults lasted on average $56.2 \pm 4.1$ days $\left(25.7 \pm 3.4^{\circ} \mathrm{C}\right.$ and $85 \pm 13 \%$ R. H.). This result is similar to the one reported by Tsai and Kirsch [19], who found the duration of the egg and the nymph stage of $52.6 \pm 12$ days at $30^{\circ} \mathrm{C}$. However, the length of these stages seems to be related to the variability of temperatures at the location, which produces different growth rates of individuals within the same niche [19]. The variation is associated with the fact that $H$. crudus is a heterovoltin, i.e., the number of generations is affected by temperature [20].

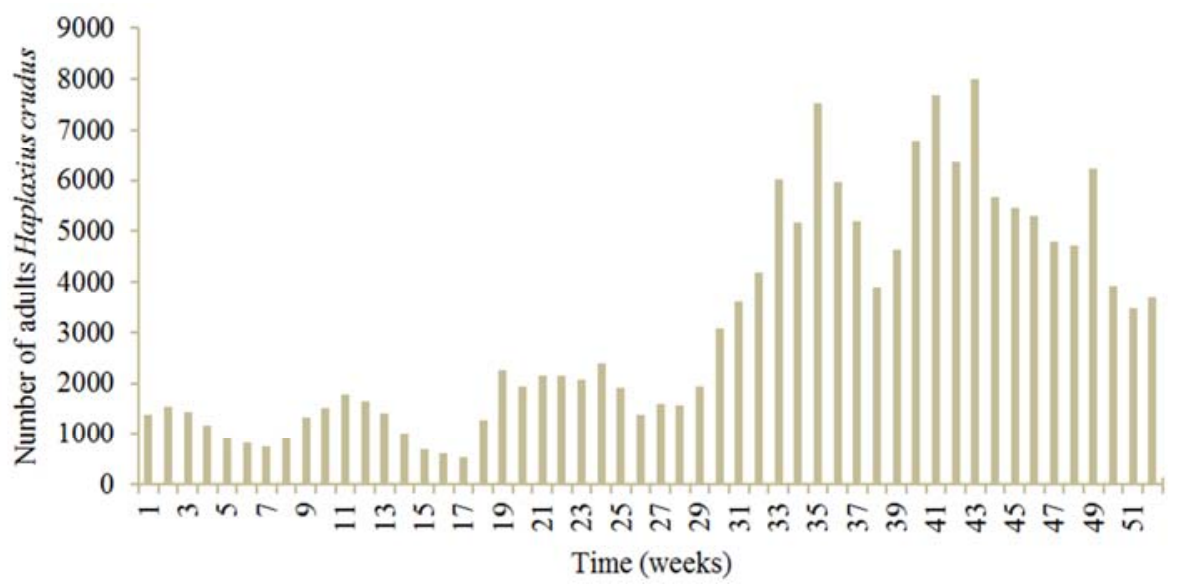

Figure 8. Weekly production of Haplaxius crudus adults at the breeding unit.

Based on the records of the emergence of $H$. crudus at the rearing unit, the average production of adults per week was $3,145,13,679$ per month, and overall production over two years of 328,294 adults. Of this total, $52.8 \%$ were females and $47.2 \%$ males, obtaining an average of 63.5 adults per infested clump of grass. However, during weeks 34 and 37, emergence rates increased to 174 adults per clump. Under these favorable environmental and infrastructure conditions, this rearing unit has a maximum infestation capacity of 360 clumps per month, with potential production of 27,000 individuals, which is sufficient to support the research studies carried out by Cenipalma.

\section{Conclusions}

Parameters were established for the mass rearing of Haplaxius crudus under shaded roof and semi-controlled environmental conditions. Furthermore, results from this research can help in the optimization of $H$. crudus mass production. With a well established mass rearing protocol, other studies can be conducted to understand aspects of this insect biology and ecology. In addition, studies for the molecular characterization of the pathogen that causes the lethal wilt disease in oil palm and on IPM approaches on biological control agents and insecticide efficacy would be more easily conducted having a well establish protocol and colonies. In the near future, more studies will also.

\section{Acknowledgements}

The authors wish to thank the Palm-growing Promotion Fund (Fondo de Fomento Palmero - FFP) for the financial support, the plantations Unipalma de Los Llanos S. A. and Palmeras del Llano S. A. for their collaboration and allow as 
to collect insects in their facilities, and finally, the research assistants Viviana Londoño and Arledys Martinez for their assistance in conducting the study.

\section{References}

[1] Howard, F., Gallo, S. (2006). El cixiido americano de las palmas, Myndus crudus Van Duzee (Insecta: Hemiptera: Auchenorrhyncha: Fulgoroidea: Cixiidae). University of Florida- IFAS Extension. 8 p.

[2] Silva, F. G., Passos, E. M., Diniz, L. E. C., Teodoro, A. V., Talamini, V., Fernandes, M. F., Dollet, M. (2019). Occurrence in Brazil of Haplaxius crudus (Hemiptera: Cixiidae), Vector of Coconut Lethal Yellowing. Neotropical Entomology 48 (1): 171-174.

[3] Arango, M., Ospina, C. A., Sierra, L. J., Martínez, G. (2011). Myndus crudus: vector del agente causante de la marchitez letal en palma de aceite en Colombia. Palmas 32 (2): 13-25.

[4] Torres, E., Tovar, J. (2004). Estudio epidemiológico de la enfermedad marchitez letal de la palma de aceite en plantaciones de Villanueva, Casanare. Palmas 25 (2): 210-211.

[5] Fedepalma (2015) Informe de gestión. https://web.fedepalma.org/bigdata/InformedeGestiondeFedepa lma2015.pdf.

[6] Fedepalma (2018) Informe de gestión. http://web.fedepalma.org/sites/default/files/files/Fedepalma/In forme-Fedepalma-2018_compressed.pdf.

[7] Howard, F. W., Moore, D., Giblin-Davis, R. M., Abad, R. G. (2001). Insects on palms. Wallingford, UK, CABI Publishing. $400 \mathrm{p}$.

[8] Zenner De Polanía, I., Lopez, A. (1977). Apuntes sobre la biología y hábitos del Haplaxius pallidus, transmisor de la 'marchitez sorpresiva' en palma africana. Revista Colombiana de Entomología 3 (1-2): 49-62.

[9] Bustillo, A. E., Arango, C. M. (2016). Las mejores prácticas para detener el avance de la marchitez letal (ML) en plantaciones de palma de aceite en Colombia. Palmas 37 (4): 75-90.

[10] Beltrán, A. I. B., Bustillo, P. A. E., García, L. J. (2019). Biología de Haplaxius crudus Van Duzee (Hemiptera: Cixiidae), vector de la Marchitez Letal en palma de aceite. Memorias, 46
Congreso Sociedad Colombiana de Entomología. Medellín, Colombia.http://www.socolen.org.co/images/stories/pdf/46_con greso.pdf.

[11] Moya, O. M., Bustillo P. A. E. (2015). Desarrollo de una cría masiva de Haplaxius crudus que permite investigaciones para el control de la Marchitez Letal. Póster, XVIII Conferencia Internacional sobre Palma de Aceite. Cartagena, Colombia. https://www.researchgate.net/publication/319649689.

[12] Beltrán, A. I. J., Londoño, L. V., Rivera, Y., Bustillo, P. A. E. (2017). Cría masiva de Haplaxius crudus (Hemiptera: Cixiidae), para el suministro de insectos con fines experimentales. Póster, XIV Reunión Técnica Nacional de Palma de Aceite. Bogotá, Colombia. http://web.fedepalma.org/sites/default/files/files/Cenipalma/po steres-rt-nacional/4_Cria_masiva_de_Haplaxius_crudus.pdf.

[13] Sierra, L. J., Bustillo, A., Rosero, G., Gutiérrez, H., Martínez, J. (2014). Plantas hospederas del vector de la Marchitez letal, Haplaxius crudus, en plantaciones de palma de aceite. Cenipalma. Ceniavances 177: 1-4 p.

[14] Lapointe, S. L., Sotelo, G., Serrano, M. S., Arango, G. (1989). Cría masiva de especies de cercópidos en invernadero. Pasturas Tropicales 11 (3): 25-28.

[15] Barrios, C. E., Bustillo, P. A. E. (2016). El ácaro rojo Raoiella indica Hirst (Acari: Tenuipalpidae) no es una plaga de la palma de aceite. Palmas 37 (2): 11-18.

[16] Tsai, J. H., Woodiel, N. L., Kirsch, O. H. (1976). Rearing techniques for Haplaxius crudus (Homoptera: Cixiidae). Florida Entomologist 59 (1): 41-44.

[17] Eden-Green, S. J. (1978). Rearing and transmission techniques for Haplaxius sp. (Hom: Cixiidae, a suspected vector of lethal yellowing disease of coconuts. Annals of Applied Biology 89 (2): 173-176.

[18] Howard, F. W., Edwards, G. B. (1984). Web-building spiders on coconut palms and their prey (Arachnida; Araneae). Folia Entomológica Mexicana (62): 81-87.

[19] Tsai, J. H., Kirsch, O. H. (1978). Bionomics of Haplaxius crudus (Homoptera: Cixiidae). Environmental Entomology 7 (2): 305-308.

[20] Halbert, S. E., Wilson, S. W., Bextine, B., Youngblood, S. B. (2014). Potential planthopper vectors of palm phytoplasmas in Florida with a description of a new species of the genus Omolicna (Hemiptera: Fulgoroidea). Florida Entomologist 97 (1): 90-98. 